\title{
Uwaga na twórczość! Poznawcze aspekty kreatywności ${ }^{1}$
}

\begin{abstract}
Abstrakt
Głównym problemem badawczym jest różnicowanie stanu uwagi w czasie wykonywania zadań konwergencyjnych i dywergencyjnych. Zadania dywergencyjne wiązane są z procesami twórczymi. Zadania te wymagają różnorodnych i często nowych rozwiązań. Niezbędne jest wówczas aktywowanie w pamięci roboczej informacji słabo połączonych z siecią pamięci długotrwałej. Kluczowym procesem w aktywowaniu informacji w pamięci jest uwaga. Postawiona została hipoteza mówiąca, że zadania dywergencyjne są wykonywane przy większej ekstensyfikacji uwagi niż zadania konwergencyjne. Procedura badawcza wykorzystana w przeprowadzonym eksperymencie opierała się na jednoczesnym wykonywaniu zadania konwergencyjnego (odtwarzania zapamiętanej melodii) lub dywergencyjnego (improwizacja w oparciu o zapamiętaną melodię), przy jednoczesnym rozwiązywaniu testu mierzącego ekstensywność uwagi. Uzyskane wyniki wspierają postawioną hipotezę. Procesy twórcze zależą od stanu uwagi i jej aktywnego działania.
\end{abstract}

Słowa kluczowe: twórczość, uwaga, pamięć robocza, improwizacja.

\section{Focus on creativity! Cognitive aspects of creativity}

\begin{abstract}
The main research problem is the differentiation of the state of attention during convergent and divergent tasks. Divergent tasks are associated with creative processes. These tasks require varied and often new solutions. It is necessary then to activate, in the working memory, information poorly connected to the long-term memory network. The key process in activating information in memory is attention. A hypothesis was that divergent tasks are performed with greater extensiveness of
\end{abstract}

\footnotetext{
* Akademia Muzyczna w Krakowie.

1 Nota: Przedstawione $\mathrm{w}$ artykule badanie zostało przeprowadzone w ramach zadania badawczego „Psychologiczne aspekty wykonawstwa muzycznego”, finansowanego przez Akademię Muzyczną w Krakowie. Dziękuję Pani dr Annie Kalarus za pomoc przy wyborze materiału eksperymentalnego i wsparcie przy procesie oceny wykonań.
} 
attention than convergent tasks. The research procedure used in the conducted experiment was based on the simultaneous execution of the extensive attention test and a convergent task (recalling the remembered melody) or a divergent task (improvisation based on the remembered melody). The results support the hypothesis. Creative processes depend on the state of attention and its active application.

Keywords: creativity, attention, working memory, improvisation.

\section{Wprowadzenie}

Pamięć robocza (working memory - WM) jest mechanizmem poznawczym, którego zadaniem jest krótkotrwałe przechowywanie informacji w celu wykorzystania ich oraz dokonywania operacji na tych informacjach (Baddeley 1986; Miyake, Shah 1999; Orzechowski, Piotrowski, Balas, Stettner 2009). Takie przedstawienie funkcji WM oznacza, że jest to struktura umysłowa odpowiedzialna za myślenie i rozumowanie. Proces tworzenia opiera się na zestawieniu reprezentacji umysłowych w nowy sposób w procesie myślenia (Finke, Ward, Smith 1992: 130; Runco, Chand 1995: 250-252; Piotrowski 2015: 40-43). Wymaga to zaangażowania wiedzy zgromadzonej w pamięci długotrwałej (long term memory - LTM). Jednak, by pojawił się nowy pomysł, wykorzystanie wiedzy z LTM nie może być schematyczne, automatycznie powielające znane wzorce. Nie może iść po linii najmniejszego oporu (Ward 1994). Tymczasem w spontanicznym wytwarzaniu pomysłów (nie mówimy tu o wykorzystaniu wyuczonych w treningach twórczości technikach czy heurystykach twórczych) aktywacja informacji w sieci LTM jest zawężona do typowych powiązań. Poruszany w tym artykule problem dotyczy specyficznych związków pamięci roboczej i stanów uwagi z procesem twórczym.

Rola pamięci roboczej w procesie twórczym była przedmiotem badań Carstena De Dreu z zespołem (De Dreu i in. 2012). W serii badań nad pojemnością pamięci roboczej (working memory capacity - WMC) wykazali oni, że osoby potrafiące przechować czasowo w pamięci roboczej więcej elementów miały także wyższe wyniki w zadaniach wymagających trafnego i odległego kojarzenia (10 zadań z testu odległych skojarzeń: remote association task - RAT). Model wyjaśniający ich wyniki wskazuje na istotny wpływ pojemności pamięci roboczej na oryginalność i wytrwałość oraz na brak istotnego wpływu WMC na giętkość myślenia (różnorodność pomysłów: Guilford 1967: 325). Zadania wykorzystywane do pomiaru pojemności pamięci roboczej wymagają silnego skupienia uwagi. Efekty wskazujące na giętkość myślenia wymagają poszukiwania rozwiązań nie w ograniczonym obszarze pamięci, lecz w jak najszerszych jej rejonach. Zatem powyższe wyniki nie są zaskakujące. Giętkość wymaga powiązania w sposób nowy i nietypowy warunków zadania z informacjami zmagazynowanymi w LTM. Procedury badania pojemności 
pamięci opierają się na określaniu liczby przechowywanych elementów (Piotrowski, Stettner, Wierzchoń, Balas, Bielecki 2009: 48-55), a nie sprawności przeszukiwania pamięci długotrwałej w celu znalezienia inspirujących informacji. Przeszukiwanie pamięci jest działaniem, w którym uwaga jest aktywnie kierowana na treści pamięciowe.

Nelson Cowan (1999) i Klaus Oberauer (2002) traktują pamięć roboczą jako zaktywowaną część pamięci długotrwałej. Ten model jest bardzo przydatny do wyjaśnienia zjawiska wpływu uwagi na procesy twórcze. By pamięć robocza mogła operować informacjami, musi na nie zostać skierowana uwaga (Baddeley 1993: 152-170). Nieliczne informacje w ognisku uwagi są dostępne świadomości. Liczba elementów objęta ogniskiem uwagi w danym momencie waha się w zależności od badacza. Cowan twierdził, że pojemność ogniska uwagi to maksymalnie cztery elementy. Z kolei Klaus Oberauer (2002) i Brian McElree (2001) podają bardzo przekonujące dowody na to, że ognisko uwagi nie może zawierać więcej niż jeden element na raz (szersza analiza dostępna jest w książce Jarosława Orzechowskiego 2012). Informacje poza aktualnie skierowaną uwagą stają się z czasem coraz trudniej dostępne (potrzeba więcej wysiłku i czasu, by je przywołać w świadomości). To powiązanie zanikania informacji $\mathrm{w}$ czasie $\mathrm{z}$ procesami uwagowymi jest niezwykle istotne. Aktualnie toczy się gorący spór o naturę zanikania informacji z pamięci roboczej. Część badaczy (Barrouillet, Camos 2007; Ricker, Vergauwe, Cowan 2016) uznaje, że wraz z upływem czasu elementy nieaktywowane uwagą tracą swoją aktywację na tyle, że niemożliwe staje się ich ponowne przywołanie do świadomej pamięci. Innymi słowy, jeśli uwaga nie zostanie skierowana na daną informację ponownie poprzez powtarzanie jej $w$ myślach, zostanie ona zapomniana.

Druga grupa badaczy (Oberauer, Lewandowsky 2014) wiąże zapominanie niezaktywowanych informacji tzw. interferencją czasową. Im dłużej informacja jest przechowywana w WM, tym większy „tłok poznawczy” zaczyna się robić wokół niej. Później zapamiętywane informacje osłabiają dostępność tych wcześniejszych. Zogniskowana na informacji uwaga powoduje wzrost aktywacji i zwiększa dostępność metapoznawczą tej informacji. Traktowanie pamięci roboczej jako aktywnej części pamięci długotrwałej rzuca światło na mechanizmy wydobywania i poszukiwania w pamięci wiadomości potrzebnych do rozwiązania problemu.

Uwaga może być świadomie kierowana na informacje w sieci LTM. Jednak kierowanie uwagą może być także zautomatyzowane. Doskonałym przykładem takiego zjawiska jest „jazda na pamięć” u kierowców. Uwaga monitoruje najważniejsze działania, ale w sposób zautomatyzowany. Kiedy pojawia się jakieś odstępstwo od typowego przebiegu jazdy, może włączyć się uwaga w pełni świadoma lub to odstępstwo może zostać niezauważone (np. zmiana organizacji ruchu). Zatem jedną z ról uwagi w WM jest poszukiwanie i aktywowanie informacji przechowywanych w LTM, które mogą być pomocne w rozwiązywaniu zadania. Przykładowo, 
proste zadania arytmetyczne, jak $4+7+9=$ ?, powodują aktywowanie się reprezentacji liczb 4, 7 i 9, uruchomienia wiedzy związanej z procedurą dodawania oraz aktywowania kolejnych wyników w pamięci (dorosłe osoby, wyćwiczone w wykonywaniu prostego sumowania będą raczej przypominały sobie wyniki niż dokonywały obliczeń). Wymienione zaktywowane informacje stanowią zawartość WM w czasie rozwiązywania zadania. Oczywiście kluczową rolę w aktywowaniu tych informacji pełni uwaga. Procesy kontrolne działają w taki sposób, by poszukiwać informacji adekwatnych i hamować te, które mogą przeszkadzać. Powyższy przykład jest ilustracją funkcjonowania pamięci w zadaniach konwergencyjnych, kiedy poszukiwana jest jedna odpowiedź.

W zadaniach dywergencyjnych wymagających poszukiwania wielu możliwych odpowiedzi lub różnych sposobów dojścia do odpowiedzi uwaga może funkcjonować nieco inaczej niż w zadaniach konwergencyjnych. Zazwyczaj w tym kontekście rozróżnia się uwagę skupioną (narrow) i rozproszoną (broad) (Friedman i in. 2003; Friedman, Förster 2010). Alina Kolańczyk (2011) precyzuje te stany uwagi, rozróżniając uwagę intensywną i ekstensywną. Pierwszy rodzaj wiąże z głębokim przetwarzaniem informacji i silnym skupieniem uwagi. W kontekście sieciowej architektury LTM i aktywacyjnych modeli WM uwaga intensywna aktywowałaby blisko i silnie powiązane struktury (np. w obrębie kategorii, typowych skojarzeń, wyćwiczonych procedur). Z kolei uwaga ekstensywna aktywowałaby większy i słabiej powiązany zakres informacji w sieci LTM.

W zadaniach twórczych konieczne są zarówno procesy konwergencyjne, jak i dywergencyjne (Treffinger, Isaksen, Dorval 1997). Zatem pojawią się także związane z nimi ekstensywne i intensywne stany uwagi. Co najmniej od czasów opisania techniki burzy mózgów (Osborn 1942: 28-30) twórcy wykorzystują praktycznie użyteczną zasadę oddzielania procesów generowania idei od procesów ocennych. Ta zasada najwyraźniej ma pokrycie w opisanych wyżej mechanizmach uwagowych pamięci roboczej. Uwaga zintensyfikowana potrzebna do analizy pomysłu podczas dokonywania oceny nie pozwala jednocześnie na aktywację odległych i słabo powiązanych informacji, i tym samym inspirację do rozwiązań nowych. I vice versa - zekstensyfikowana uwaga nie pozwoli na głębokie przeanalizowanie wartości pomysłu.

W praktyce badawczej trudno jednak zmierzyć stan uwagi w czasie zadań poznawczych. Trudność ta pojawia się zwłaszcza przy próbach pomiaru stanu uwagi ekstensywnej. Zazwyczaj samo wykonywanie zadania eksperymentalnego powoduje konieczność skupienia się. Najczęściej pojawiają się próby wywołania wstępnie stanu uwagi ekstensywnej zadaniem i dokonania pomiaru uwagi tuż po wykonaniu zadania. Przykładem takiej procedury są np. badania, w których badani wchodzili w stan medytacji (Kolańczyk, Mikołajczyk 2011). Tymczasem odpowiedź na pytanie, czy rzeczywiście zadania dywergencyjne i konwergencyjne różnią się stanem uwagi, wymaga zbadania stanu uwagi w czasie wykonywania zadań. 
Opisany poniżej eksperyment jest próbą badania intensyfikacji/ekstensyfikacji uwagi w czasie wykonywania zadań konwergencyjnych i dywergencyjnych. Zadaniami badawczymi było wykonywanie muzyki. Osoby badane miały nucić zapamiętaną melodię lub improwizować na jej temat. By zwiększyć prawdopodobieństwo poprawnego wykonania zadań muzycznych przez osoby badane, eksperyment przeprowadzono na studentach Akademii Muzycznej w Krakowie. Głównym założeniem teoretycznym jest charakter zadania muzycznego. W wynikach wcześniejszych badań nad wykonawstwem muzyki można znaleźć wskazówki, które pozwalają wiązać improwizację z procesami dywergencyjnymi, a odpamiętywanie słyszanego utworu z procesami konwergencyjnymi. Roger Beaty z zespołem (2013: 5) w badaniach nad muzykami uzyskali model wskazujący, że na jakość improwizacji muzycznej wpływają głównie dwa czynniki: czas ćwiczeń oraz sprawność myślenia dywergencyjnego (badania testem niezwykłych zastosowań Joya Guilforda). Z kolei badania z wykorzystaniem neuroobrazowania za pomocą funkcjonalnego rezonansu magnetycznego, prowadzone przez Monicę López-Gonzalez i Charlesa Limba (2012: 6-8) wskazują na zmiany w aktywacji kory przedczołowej związanej $\mathrm{z}$ uwagą podczas przypominania sobie melodii i improwizowania.

\section{Eksperyment}

W badaniach wzięło udział 41 osób. Wszyscy byli muzykami, studentami różnych lat w Akademii Muzycznej w Krakowie. Jednak wyniki 11 osób zostały zakwestionowane przez 2 sędziów kompetentnych - pracowników naukowych i dydaktycznych Akademii Muzycznej jako niespełniające wymogów zadania. Analizę statystyczną przeprowadzono na wynikach 30 osób (średnia wieku $=23,8, S D=5$ ), 15 osób z grupy kontrolnej wykonującej utwór (7 kobiet i 8 mężczyzn) i 15 osób z grupy eksperymentalnej improwizującej na bazie muzyki (6 kobiet i 9 mężczyzn). Wszyscy badani wyrazili zgodę na dobrowolny udział w badaniach i informowani byli o możliwości przerwania badań w dowolnym momencie na ich żądanie. Badani byli wolontariuszami i nie pobierali wynagrodzenia za udział w badaniach.

\section{Materiał i procedura}

Zadaniem wszystkich osób badanych było zapamiętywanie melodii. W eksperymencie użyto nagranie $\mathrm{w}$ formacie mp3 zawierające wykonanie melodii na pianinie oraz zapis nutowy prezentowany na kartce papieru (rycina 1). Muzykę prezentowano w słuchawkach z mikrofonem. Do nagrania wykonania zapamiętanej melodii użyto mikrofonu i aplikacji Windows Sound Recorder. 


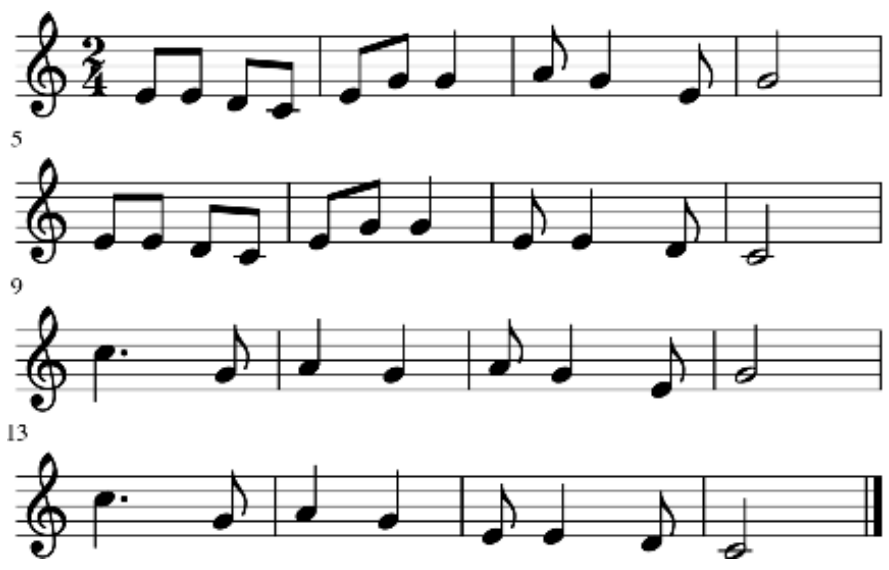

Ryc. 1. Zapis melodii prezentowany osobom badanym

Jako drugie zadanie wykorzystany został test uwagi ekstensywnej (Roczniewska, Sterczyński, Popławska, Kolańczyk 2012). W niniejszym badaniu wykorzystana została komputerowa wersja testu, napisana w programie Inquisit 4.0. Test zawiera 360 liter (a; d; e; k; s; w) ułożonych w 11 koncentrycznych elips. Każda litera występuje w teście 60 razy. Osoby badane mają za zadanie znaleźć jak najwięcej liter 'd'. Zaznaczona przez osobę badaną litera zmienia kolor z czarnego na zielony (rycina 2). Czas rozwiązywania całego zadania wynosi 2 minuty. Test prezentowano przy użyciu laptopa z ekranem 17". Badania przeprowadzano indywidualnie w sali ćwiczeniowej Akademii Muzycznej w Krakowie.

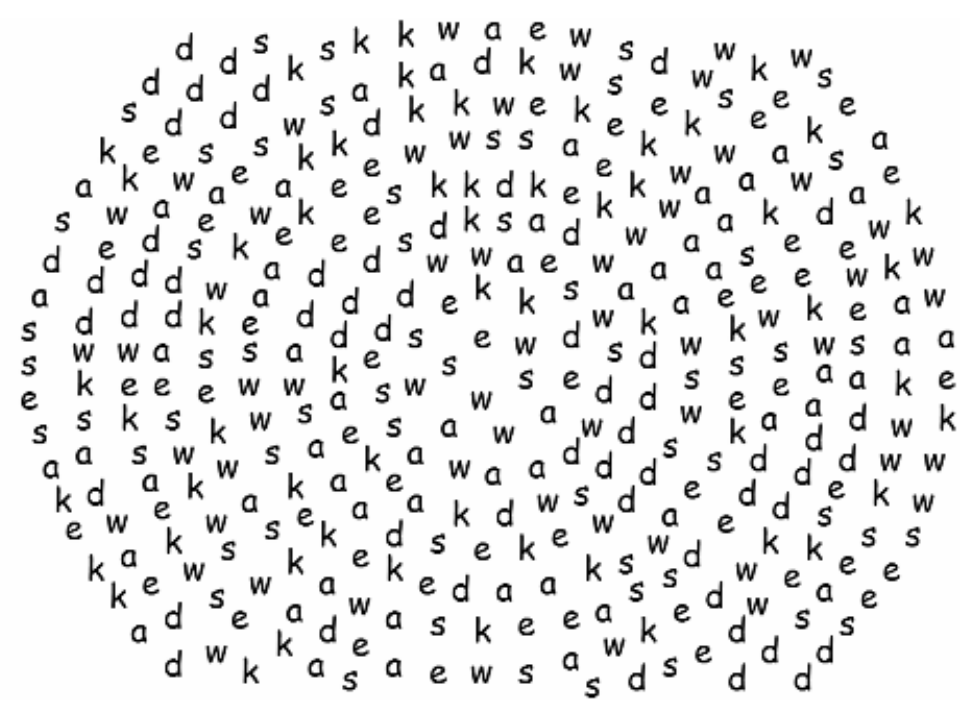

Ryc. 2. Rozmieszczenie liter w teście Elips (Roczniewska i in. 2012: 127). Za zgodą autorów 
Przed rozpoczęciem eksperymentu badani proszeni byli o wymyślenie pseudonimu, oraz o uzupełnienie danych dotyczących płci, wieku i profilu wykształcenia. Eksperyment został zaprojektowany w paradygmacie zadania podwójnego (Piotrowski, Stettner, Wierzchoń, Balas, Bielecki 2009: 64-66). Manipulacja polegała na zmianie głównego zadania. Przed rozpoczęciem badania osoby badane miały zapamiętać zadaną melodię. Melodia prezentowana była trzykrotnie, jednocześnie osoby badane mogły czytać zapis nutowy na kartce. Po fazie zapamiętywania następowała właściwa część eksperymentu. Głównym zadaniem osób badanych w grupie pierwszej było jak najdokładniejsze powtórzenie zapamiętanej melodii, nucąc ją lub śpiewając. W grupie drugiej osoby badane miały na głos improwizować na temat zapamiętanej melodii. Badani mieli jednocześnie wykonywać test Elips na ekranie komputera. Nucenie melodii miało trwać przez cały czas rozwiązywania tego testu.

\section{Wyniki}

Przed przystąpieniem do analiz statystycznych nagrania wykonań zapamiętanej melodii przez osoby badane zostały przekazane do oceny dwóm sędziom kompetentnym - pracownikom Akademii Muzycznej w Krakowie. Dokonali oni oceny wykonania pod kątem odpowiedniości do instrukcji eksperymentalnej. Sprawdzano, czy badani z grupy kontrolnej odtwarzali melodię bezbłędnie ( 2 pkt), z niewielkimi błędami (1 pkt) lub z poważnymi błędami (0 pkt). Wykonania osób z grupy eksperymentalnej oceniano jako złożoną improwizację, opartą na melodii (2 pkt), prostą improwizację opartą na melodii (1 pkt), niewielkie zmiany w melodii - praktycznie powtarzanie wyuczonej melodii (0 pkt) oraz całkowita zmiana melodii, bez odwołania się do melodii zapamiętywanej ( 0 pkt). Do analiz włączono wyniki tylko osób, które uzyskały zgodną ocenę 2 lub 1 (30 osób). Usunięto wyniki łącznie 11 osób, w tym: 5 z grupy kontrolnej i 6 z grupy eksperymentalnej.

Analizy statystyczne przeprowadzone zostały przy użyciu programu JASP 0.8.1.2 (2017). Analizie statystycznej poddano zmienne mierzone testem Elips: poprawność reakcji, liczba reakcji, średnia odległość między zaznaczonymi bodźcami ('droga'), odchylenie standardowe dla zmiennej 'droga'. W analizie wykorzystano czynnik Bayesa. Do zapisu i interpretacji czynnika Bayesa (BF) zostały wykorzystane prace autorstwa Ruuda Wetzelsa i in. (2011) oraz Alexandra Ly, Josine Verhagen i Eric-Jana Wagenmakersa (2016). Dolny indeks 10 oznacza, że wartość BF wspiera hipotezę 1 przeciwko hipotezie 0. W przeprowadzonych poniżej analizach bayesowskich hipoteza 1 oznacza obecność istotnych różnic między porównywanymi zmiennymi, natomiast hipoteza 0 oznacza, że między zmiennymi nie ma żadnych istotnych różnic. Interpretacja wartości czynnika Bayesa została przyjęta na podstawie pracy Wetzelsa i in. (2011: 293). Przyjęcie 
przez BF10 powyżej 3 jest interpretowane jako silny dowód za prawdziwością hipotezy 1. Wartość BF10 poniżej 0,33 interpretowana jest jako silny dowód na prawdziwość hipotezy 0. Wartości BF10 pomiędzy 3 i 0,33 nie są konkluzywne i nie wspierają wystarczająco żadnej z hipotez.

Poprawność liczona była jako stosunek trafnie zaznaczonych liter 'd' do wszystkich dokonanych wyborów. Poprawność dla obu grup była bardzo wysoka, dla grupy odpamiętującej melodię wynosiła 98,76\% (SD = 0,03), a dla grupy improwizującej wyniosła 98,89\% (SD = 0,02). Różnice nie były istotne statystycznie, $\mathrm{BF}_{10}=0,32$. Liczba wszystkich reakcji $\mathrm{w}$ grupie odpamiętującej melodię wyniosła 42 (SD = 11,79), a w grupie improwizującej 37,53 (SD = 8,97). Różnice międzygrupowe nie były istotne statystycznie. Jednak czynnik $\mathrm{BF}_{10}=0,7$, co oznacza, że nie można konkluzywnie stwierdzić prawdziwości hipotezy o braku różnic. Średni wynik dla zmiennej 'droga' w grupie odpamiętującej melodię wyniósł 11,5 (SD = 1,87), a w grupie improwizującej wyniósł 14,26 ( $\mathrm{SD}=4,39$ ). Wartość p sugeruje brak istotnych różnic $(\mathrm{F}(1,16)=3,88, \mathrm{p}=0,066)$, jednak analiza bayesowska wyraźnie wskazuje na silną hipotezę o różnicach między grupami $\left(\mathrm{BF}_{10}=3,29\right)$. Czynnik BF jest decydującą wskazówką co do wnioskowania o sile hipotezy.

\section{Wnioski}

W teście Elips najważniejszym dla określenia stanu uwagi wskaźnikiem jest droga (Roczniewska i in. 2012: 125). W przeprowadzonym badaniu osoby przypominające sobie melodię, a więc wykonujące zadanie konwergencyjne, poszukiwały litery 'd' w sposób charakterystyczny dla uwagi intensywnej. Z kolei osoby improwizujące szukały litery 'd', przenosząc wzrok na różne, odleglejsze od siebie obszary ekranu, co jest charakterystyczne dla bardziej zekstensyfikowanej uwagi. Zatem można odrzucić hipotezę o braku różnic między stanami uwagi dominujących w zadaniach dywergencyjnych w porównaniu do konwergencyjnych. Uogólniając, uzyskane wyniki dowodzą wprost, że w trakcie rozwiązywania zadań o charakterze dywergencyjnym uwaga ulega ekstensyfikacji.

Osoby badane miały wykonywać jednocześnie dwa zadania - wokalne i przestrzenne. Stan uwagi wywołany koniecznością wykonywania zadania konwergencyjnego wpływał istotnie na sposób wykonywania zadania przestrzennego. Stąd wniosek o jednakowym stanie uwagi dla różnych zadań. Wniosek ten można odnieść bezpośrednio do twórczego rozwiązywania problemów i rozdzielenia faz tego procesu. Poszukiwanie rozwiązań i ocena są działaniami wymagającymi różnego stanu intensyfikacji uwagi. Zatem mieszanie generowania i oceny pomysłów powoduje, że silnie skupiona uwaga musi ekstensyfikować się i intensyfikować naprzemiennie, co przeszkadza, zwłaszcza w poszukiwaniu rozwiązań. Wiele zagadnień związanych $\mathrm{z}$ funkcjonowaniem uwagi $\mathrm{w}$ procesie twórczym wymaga 
jeszcze badań. Ze względów ewolucyjnych ogniskowanie uwagi dokonuje się szybko. Nie wiemy, ile czasu zajmuje ponowne ekstensyfikowanie uwagi. Jest to zagadnienie, którym warto się zająć w kolejnych badaniach. Nie wiemy także, czy uwaga ekstensywna i intensywna jest w podobnym stopniu wysiłkowa i czy, jak twierdzi Bernhard Hommel (2012: 232), działania twórcze wiążą się z osłabieniem (większą „tolerancją”) kontroli poznawczej.

W badaniach De Dreu i in. (2012: 661-662) improwizacja muzyczna na trzy zadane tematy (możliwe tematy to „wiosna”, „lato”, „jesień”, „zima”) była oceniana przez ekspertów. U osób o większej pojemności pamięci roboczej poziom improwizacji twórczej wzrastał w kolejnych próbach, zaś u osób z mniejszą pojemnością WM poziom kreatywności malał. Jednak badania były rozłożone w czasie i traktowały WMC jako cechę indywidualną. W badaniach przedstawionych w tym artykule wykorzystana została procedura zadania podwójnego - uczestnicy mieli wykonywać dwa zadania w tym samym czasie. Ta procedura pozwoliła na rozróżnienie typu uwagi w czasie pracy pamięci roboczej przy wykonywaniu zadań dywergencyjnych i konwergencyjnych. Łącząc wiedzę uzyskaną przez De Dreu z obecnymi wynikami, można postawić tezę, że procesy twórcze, wykorzystujące słabo powiązane ze sobą elementy sieci LTM (giętkość), mogą wiązać się nie tyle z pasywnym działaniem pamięci roboczej, jakim jest jej pojemność, ale z aktywnym manipulowaniem ogniskiem uwagi i jej ekstensywnością.

Pomysł na ekstensyfikację uwagi przed twórczym rozwiązywaniem problemu jest w praktyce realizowany zazwyczaj przez specyficzne rozgrzewki twórcze oraz przez wprowadzenie elementów humoru i ludyczności (Tokarz 2005: 95-96, 103105; Szmidt 2007: 271-272). Jednak znając bardziej podstawowy mechanizm, być może będziemy mogli zaproponować ćwiczenia czy techniki bardziej dopasowane do rodzaju zadania.

Innym ciekawym wnioskiem w kierunku wsparcia działań twórczych jest wskazanie na improwizację muzyczną jako na źródło ekstensyfikacji uwagi. Być może w czasie działań twórczych w dziedzinach innych niż muzyka (np. plastycznych, językowych czy ruchowych) można oczekiwać ekstensyfikacji uwagi i w efekcie bardziej twórczych pomysłów. To oczywiście jest jedynie hipoteza wymagająca weryfikacji, szczególnie w odniesieniu do grup z doświadczeniem muzycznym i bez takiego doświadczenia. Uzyskany w naszym badaniu efekt może okazać się zawężony jedynie do osób o doświadczeniu muzycznym. Jednak idea ekstensyfikowania uwagi w innej modalności niż wykonywane zadanie może być trafna. Być może kwestią jest dobór takiego rodzaju aktywności improwizacyjnej, który nie wymagałby dodatkowego silnego kontrolowania działania, a pozwolił uwadze na swobodniejsze poszukiwanie mniej typowych informacji. Dla muzyków takim działaniem może być improwizacja muzyczna, dla innych osób - ruch lub zabawa słowami - dziedziny, w których mają już pewne doświadczenie. 


\section{Bibliografia}

Baddeley A. D. (1986) Working memory, Oxford, Clarendon Press.

Baddeley A. D. (1993) Working memory or working attention? w: Attention: Selection, awareness, and control. A tribute to Donald Broadbent, A. D. Baddeley, L. Weiskrantz (eds.), New York, Clarendon Press/Oxford University Press.

Beaty R. E., Smeekens B. A., Silvia P. J., Hodges D. A., Kane M. J. (2013), A First Look at the Role of Domain-General Cognitive and Creative Abilities in Jazz Improvisation, "Psychomusicology: Music, Mind \& Brain", no 23/4, s. 262-268.

Cowan N. (1999) An embedded-process model of working memory w: Models of working memory. Mechanisms of active maintenance and executive control, A. Miyake, P. Shah (eds.), Cambridge, England, Cambridge University Press, s. 62-101.

De Dreu C. K. W., Nijstad B. A., Baas M., Wolsink I., Roskes M. (2012) Working Memory Benefits Creative Insight, Musical Improvisation, and Original Ideation Through Maintained Task-Focused Attention, "Personality and Social Psychology Bulletin", no 38/5, s. 656-669; doi: 10.1177/0146167211435795.

Finke R. A., Ward T. B., Smith S. M. (1992) Creative cognition, Cambridge, MA, MIT Press.

Friedman R. S., Förster J. (2010) Implicit affective cues and attentional tuning. An integrative review, "Psychological Bulletin", no 136, s. 875-893.

Friedman R. S., Fishbach A., Förster J., Werth, L. (2003) Attentional priming effects on creativity, "Creativity Research Journal”, no 15/2-3, s. 277-286.

Guilford J. P. (1967) The nature of human intelligence, New York, McGraw-Hill.

Hommel B. (2012) Convergent and divergent operations in cognitive search w: Cognitive Search: Evolution, Algorithms, and the Brain. Strüngmann Forum Reports, vol. 9, P. M. Todd, T. T. Hills, T. Robbins (eds.), Cambridge, MA, MIT Press, s. 215-230.

JASP Team (2017), JASP (wersja 0.8.1.2) [Program komputerowy].

Kolańczyk A. (2011) Uwaga Ekstensywna. Model ekstensywności vs. intensywności uwagi, „Studia Psychologiczne”, nr 49/3, s. 7-27; doi: 10.2478/v10167-010-0024-X.

Kolańczyk A., Mikołajczyk P. (2011) Uwaga post-medytacyjna osób doświadczonych w medytowaniu, „Studia Psychologiczne”, nr 49/3, s. 57-74; doi: 10.2478/v10167010-0027-5.

López-González M., Limb C. J. (2012) Musical creativity and the brain, "Cerebrum", no 2, s. 1-15. 
Ly A., Verhagen A. J., Wagenmakers E. (2015) Harold Jeffreys's default Bayes factor hypothesis tests: Explanation, extension, and application in psychology, "Journal of Mathematical Psychology”, no 72, s. 19-32; doi: 10.1016/j.jmp.2015.06.004.

McElree B. (2001) Working memory and focal attention, "Journal Of Experimental Psychology-Learning Memory And Cognition", no 27/3, s. 817-835.

Miyake A., Shah P. (eds.) (1999) Models of working memory: Mechanisms of active maintenance and executive control, Cambridge, UK, Cambridge University Press.

Mumford M. D., Costanza D. P., Threlfall K. V., Baughman W. A., Reiter-Palmon R. (1993) Personality variables and problem-construction activities: An exploratory investigation, "Creativity Research Journal", no 6/4, s. 365-389; doi: 10.1080/ 10400419309534493.

Oberauer K. (2002) Access to information in working memory: Exploring the focus of attention, "Journal of Experimental Psychology: Learning, Memory, and Cognition", no 28/3, s. 411-421; doi: 10.1037/0278-7393.28.3.411.

Oberauer K., Lewandowsky S. (2014) Further evidence against decay in working memory, "Journal of Memory and Language", no 73/1, s. 15-30; doi: 10.1016/ j.jml.2014.02.003.

Osborn A. F. (1942) How to Think Up, New York, London, McGraw-Hill Book Co.

Orzechowski J. (2012) Magiczna liczba jeden, czyli co jeszcze zmieści się w pamięci roboczej, Kraków, Wydawnictwo Uniwersytetu Jagiellońskiego.

Orzechowski J., Piotrowski K. T., Balas R., Stettner Z. (red.) (2009) Pamięć robocza, Warszawa, Academica.

Piotrowski K. T. (2015) Jakie jest znaczenie różnych procesów poznawczych $w$ twórczym rozwiqzywaniu problemów? w: Kreatywność. Pytania i odpowiedzi, I. PufalStruzik, Z. Okraj (red.), Kielce, Wydawnictwo Uniwersytetu Jana Kochanowskiego w Kielcach, s. 39-44.

Piotrowski K. T., Stettner Z., Wierzchoń M., Balas R., Bielecki M. (2009) Eksperymentalne techniki badania pamięci roboczej w: Pamięć robocza, J. Orzechowski, K. T. Piotrowski, R. Balas, Z. Stettner (red.), Warszawa, Wydawnictwo Academica, s. 47-76.

Ricker T. J., Vergauwe E., Cowan N. (2016) Decay theory of immediate memory: From Brown (1958) to today (2014), "The Quarlerly Journal of Experimental Psychology", no 69/10, s. 1969-1995; doi: 10.1080/17470218.2014.914546.

Roczniewska M., Sterczyński R., Popławska A., Szamotulska B., Kolańczyk A. (2012) Test Elips Jako Narzędzie Badania Skaningu Uwagi Ekstensywnej vs. Intensywnej, „Studia Psychologiczne", nr 49/3, s. 115-128; doi: 10.2478/v10167-010-0031-y. 
Runco M. A., Chand I. (1995) Cognition and creativity, "Educational Psychology Review", no 7/3, s. 243-267.

Szmidt K. J. (2007) Pedagogika twórczości, Gdańsk, Gdańskie Wydawnictwo Psychologiczne.

Tokarz A. (2005) Dynamika procesu twórczego, Kraków, Wydawnictwo Uniwersytetu Jagiellońskiego.

Treffinger D. J., Isaksen S. G., Dorval K. B. (1997) Kreatywne rozwiqzywanie problemów, Radom, Instytut Technologii Eksploatacji.

Ward T. B. (1994) Structured imagination: the role of category structure in exemplar generation, "Cognitive Psychology", no 27, s. 1-40.

Wetzels R., Matzke D., Lee M. D., Rouder J. N., Iverson G. J., Wagenmakers E. J. (2011) Statistical evidence in experimental psychology an empirical comparison using t tests, "Perspectives on Psychological Science", no 6, s. 291-298; doi:10.1177/ 1745691611406923. 